\title{
Effect of nitrate and its reduction products on the growth and activity of the rumen microbial population
}

\author{
BY J. P. MARAIS \\ Cedara Agricultural Research Institute, Pietermaritzburg, South Africa \\ AND JOHA J. THERION AND R. I. MACKIE \\ Animal and Dairy Science Research Institute, Irene, South Africa \\ AND A. KISTNER \\ Laboratory of Molecular and Cell Biology, CSIR, Pretoria, South Africa \\ AND C. DENNISON \\ Department of Biochemistry, University of Natal, Pietermaritzburg, South Africa
}

(Received 7 April 1987 - Accepted 2 October 1987)

\begin{abstract}
1. The nature of the digestion-inhibiting substance in Kikuyu grass (Pennisetum clandestinum, Hochst), containing high levels of nitrate, was investigated using in vitro digestibility techniques.

2. Nitrite, which accumulated during the reduction of nitrate to ammonia, seemed to be the primary factor reducing digestibility. Nitrate and ammonia did not affect digestion in vitro.

3. Nitrite caused a reduction in the cellulolytic, xylanolytic and total microbial population, with a concomitant reduction in cellulase and xylanase activity of the digesta.

4. The mode of action of nitrite on rumen microbial growth was investigated.

5. The possibility that the growth of cellulolytic rumen microbes was depressed by a reduction in concentration of essential branched-chain volatile fatty acids by nitrite was discounted.

6. Although nitrite caused a marked increase in the redox potential, due to its oxidizing properties, the morepositive redox potential did not reduce the digestibility of the grass.

7. The growth of three of the four major cellulolytic bacteria commonly found in the rumen was severely depressed by nitrite, while some rumen bacteria were relatively insensitive to nitrite.

8. Growth inhibition seemed to depend primarily on the extent to which these microbes derive their energy from electron-transport-mediated processes.

9. It was suggested that, due to the sensitivity of some rumen bacteria to nitrite, digestibility and therefore animal performance could be affected long before clinical symptoms of nitrite toxicity become apparent.
\end{abstract}

Elevated levels of nitrate in feeds, water and food products could pose a serious threat to animal and human health due to its conversion to toxic nitrite. Ruminants are particularly susceptible, as nitrate is reduced to ammonia by certain rumen microbes, with nitrite as an intermediate product. Under some conditions the rate of nitrite formation may exceed the rate of nitrite reduction to ammonia, resulting in elevated nitrite levels. Animals which consume a high-nitrate diet, can adapt by reducing nitrate and nitrite more rapidly due to a large increase in nitrate-metabolizing microbes in the rumen (Allison \& Reddy, 1984). However, adaptation may not occur in animals under rotational grazing systems of management since nitrate levels of pastures can vary appreciably. Instances of nitrite poisoning on cultivated pastures are therefore common (Turner \& Kienholz, 1972; Kemp et al. 1976; Kromann et al. 1976).

The harmful effect may be due to the oxidizing properties of nitrite, whereby blood haemoglobin is converted into methaemoglobin. Consequently the blood loses its function as an oxygen carrier, resulting in anoxia of the animal (Vertregt, 1977). Nitrite also acts as a vasodilator which could cause a fatal reduction in blood pressure (Holtenius, 1957; 
Asbury \& Rhode, 1964). In recent years, a number of observations have led to concern about the potential risk to animal and human health, due to possible carcinogenic effects as a result of interactions between nitrite and substances such as amines and amides, to produce N-nitroso compounds (Van Broekhoven \& Davies, 1980, 1981; Committee on Nitrite and Alternative Curing Agents in Food, 1981).

Apart from the previously described direct effects on animal and human health, nitrite or nitrate, or both, may, more subtly, also influence the rumen microbial population. Although compensatory hind-gut fermentation is possible, animal production in ruminants could be adversely affected by a decrease in rumen digestion. Earlier workers found no harmful effects other than a transient methaemoglobinaemia in animals consuming sublethal amounts of nitrate (Jamieson, 1959), but more recent studies showed a reduction in digestibility of forages or pure cellulose in vitro in the presence of nitrate (Hall et al. 1960; Miyazaki et al. 1974; Marais, 1980). Furthermore, nitrite is a well-recognized antimicrobial agent. Despite its general use in the meat-processing industry, the mechanism of bacterial inhibition has not been satisfactorily elucidated (Hansen \& Levin, 1975; O'Leary \& Solberg, 1976; Yarbrough et al. 1980). At present, little is known of the chemical changes within the rumen associated with the intake of high-nitrate feeds, which lead to a decline in digestibility. This lack of information prompted the investigation reported here.

Experiments were conducted by means of digestibility studies on samples of Kikuyu grass (Pennisetum clandestinum, Hochst) containing high levels of nitrate, to determine which substances reduce the digestibility. Attempts were also made to determine the mode of action of these substances.

MATERIALS AND METHODS

Measurement of in vitro fermentation and digestibility

The method used for in vitro fermentation studies was based on the two-stage procedure described by Tilley \& Terry (1963), subsequently modified by Minson \& McLeod (1972). Rumen fluid inocula $(250-500 \mathrm{ml} / \mathrm{sheep})$ were obtained by means of a suction-strainer technique (Raun \& Burroughs, 1962) from South African Mutton Merino wethers fed on $2.5 \mathrm{~kg}$ lucerne (Medicago sativa) hay and $100 \mathrm{~g}$ whole maize daily. Samples of Kikuyu grass were digested in the presence and absence of nitrate (added as potassium nitrate) for periods ranging from 0 to $72 \mathrm{~h}$ under anaerobic conditions at $39^{\circ}$. Redox-potential measurements and microbial counts were performed on these digests, as well as analyses for volatile fatty acids, nitrate, nitrite, ammonia and carbohydrase activity. For digestibility determinations, microbial fermentation was followed by an acid pepsin (EC 3.4.23.1) digestion (Minson \& McLeod, 1972).

\section{Enumeration of viable rumen bacteria}

Grass digests were homogenized with an Ultra Turrax homogenizer (type TP 18/10; Ganke \& Kunkel, West Germany) under anaerobic conditions to dislodge bacteria from solid plant particles. Counts were made on samples of the homogenate. The procedure was based on the enumeration of viable cellulolytic, xylanolytic and total bacteria grown on selective solid culture media in roll-tubes under anaerobic conditions (Kistner, 1960).

\section{Cellulase and xylanase activity}

Since more than $90 \%$ of the carbohydrase activity of rumen digests is firmly associated with the particulate material (Francis et al. 1978), enzyme assays were done on freeze-dried samples of the washed grass residue from digests in vitro. Cellulase activity was determined by incubating samples of residue with carboxymethylcellulose substrate, as described by Krishnamurti \& Kitts (1969), and determining the reducing sugars released by means of a 
modified Somogyi procedure (Marais et al. 1966). The assay for xylanase activity in residue samples was based on the analysis of reducing sugars released by the hydrolysis of Larchwood (Larix sp.) xylan (Sigma Chemical Co., Poole, Dorset) (Tiaz \& Honigman, 1976). Temperature-denatured grass residues were used as controls.

\section{Measurement of specific growth rate}

Rumen bacteria. Bacteroides succinogenes S85 and Ruminococcus flavefaciens FD1 were obtained from the culture collection of M. P. Bryant, University of Illinois, USA. Ruminococcus albus 22.08.6A and Butyrivibrio fibrisolvens $\mathrm{Ce} 51$ were from the culture collection of the Anaerobic Microbiology Division, CSIR Laboratory for Molecular and Cell Biology, South Africa, while Selenomonas ruminantium subsp. lactilytica ATCC 19205 was obtained from the American Type Culture Collection, Rockville, Md, USA.

Medium. The medium was based on medium 10 of Caldwell \& Bryant (1966) and had the following composition (mmol): $\mathrm{K}_{2} \mathrm{HPO}_{4} 1 \cdot 8, \mathrm{KH}_{2} \mathrm{PO}_{4} 1 \cdot 4,\left(\mathrm{NH}_{4}\right)_{2} \mathrm{SO}_{4} 3 \cdot 7, \mathrm{NaCl} 0 \cdot 82$, $\mathrm{MgSO}_{4} 0 \cdot 41, \mathrm{CaCl} 0 \cdot 58$, acetic acid $32 \cdot 0$, propionic acid 8.6, butyric acid $4 \cdot 6$, isobutyric acid $1 \cdot 2$, isovaleric acid $1 \cdot 0$, DL- $\alpha$-methylbutyric acid $1 \cdot 0$, hemin 0.0016 , cellobiose $9 \cdot 4$ (or glucose 17.9 in medium for Selenomonas ruminantium). The medium contained Trypticase (Merck) $2.15 \mathrm{~g} / \mathrm{l}$, yeast extract $0.54 \mathrm{~g} / 1$ and $\mathrm{NaHCO}_{3}$ added as solid to adjust the $\mathrm{pH}$ to either 6.0 or 6.8 . The medium was kept at $38.5^{\circ}$ under anaerobic conditions.

Membrane-filter-sterilized $9 \cdot 3 \mathrm{ml}$ portions of medium were transferred under anaerobic conditions to $20 \mathrm{ml}$, optically-matched culture bottles. Cysteine and sodium sulphide from a sterile stock solution were injected in $0.2 \mathrm{ml}$ volumes into the culture bottles to give final concentrations of $1.6 \mathrm{mmol}$ and $1.0 \mathrm{mmol}$ respectively. Potassium nitrite from sterile stock solutions was injected in $0.5 \mathrm{ml}$ volumes into the culture bottles to give final concentrations ranging from 0.5 to $32 \mathrm{mg}$ nitrogen $/ 1$.

Measurement of growth. Growth was measured, in triplicate, as an increase in turbidity at $578 \mathrm{~nm}$. When growth occurred, readings were continued until the turbidity reached the limit of a satisfactory linear relation with biomass. Well-documented techniques (Koch, 1981) were used to calculate specific growth rates from the turbidity measurements.

\section{Analytical methods}

Nitrate, nitrite and ammonia were determined on samples of the digest by the colorimetric procedures of Cataldo et al. (1975), Nicholas \& Nason (1957) and Weatherburn (1967) respectively.

Volatile fatty acids were analysed by gas-liquid chromatography (model 5790; Hewlett Packard) equipped with a flame-ionization detector and a $2-\mathrm{m}$ glass column $(3.0 \mathrm{~mm}$ internal diameter), packed with $10 \%$ SP $1000 / 1 \%$ phosphoric acid on $100 / 120$ Chromosorb W-AW (Supelco Inc., Bellefonte, Pennsylvania). The carrier gas was high purity $\mathrm{N}_{2}(30 \mathrm{ml} / \mathrm{min})$. The inlet, column and detector temperatures were maintained at $250^{\circ}, 160^{\circ}$ and $200^{\circ}$ respectively. Aqueous samples of digest, containing $50 \mathrm{~g}$ metaphosphoric acid/1, were centrifuged and used for analysis. The peaks were automatically integrated (3390A Integrator; Hewlett Packard).

Redox potential was measured under anaerobic conditions with a $\mathrm{pH}$ meter reading $\mathrm{mV}$. A platinum electrode was used with a standard calomel electrode as reference. The platinum electrode consisted of a polished platinum rod (diameter $1.0 \mathrm{~mm}$ ) enclosed in a glass tube $(100 \mathrm{~mm} \times 8 \mathrm{~mm})$. The tip of the platinum rod protruded $30 \mathrm{~mm}$ from the end of the glass tube. Both electrodes were mounted through holes in a rubber stopper which fitted the glass digestion vessel used in these experiments. The digests were gently stirred by means of a magnetic stirrer and the most-negative reading obtained within 2 min was recorded. These values were corrected for the electrodes used (Kjaergaard, 1977). 

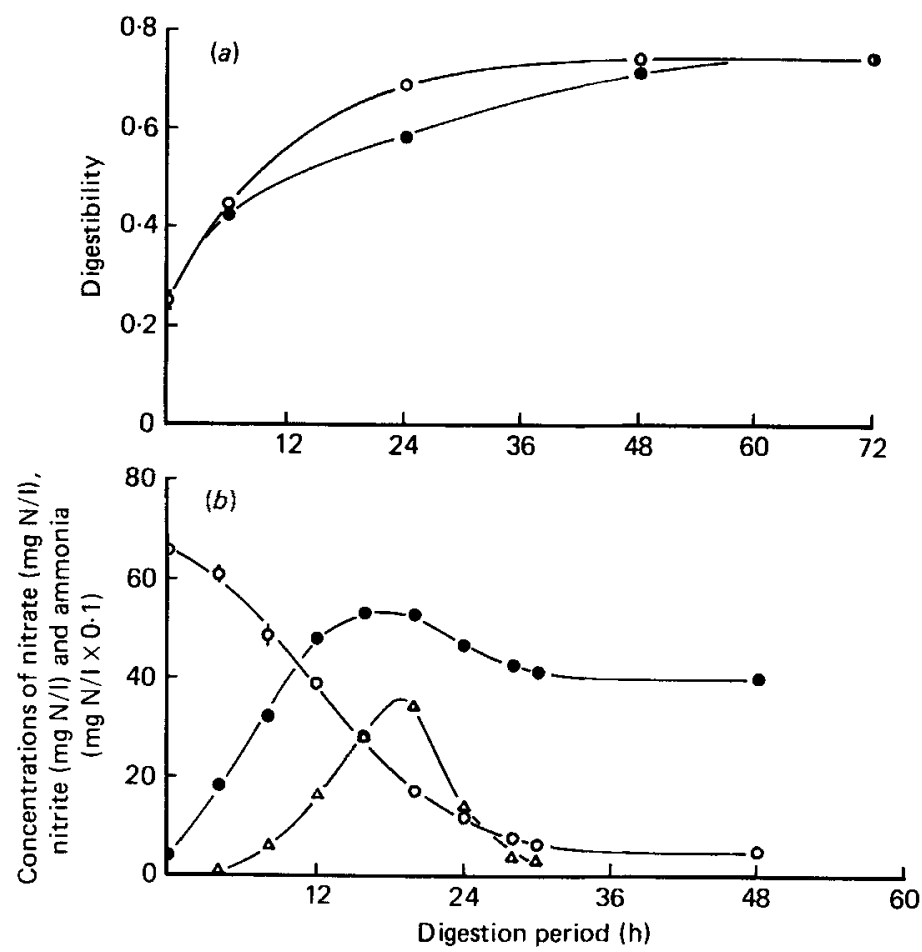

Fig. 1. Digestion of Kikuyu grass (Pennisetum clandestinum) samples by a mixed population of rumen micro-organisms in vitro in the presence of nitrate. For high-nitrate samples the nitrate-nitrogen content was adjusted to $6 \mathrm{~g} / \mathrm{kg}$ dry matter by the addition of potassium nitrate before incubation. (a) Rate of dry matter digestion. (O), Control sample (low-nitrate); (O), high-nitrate sample. (b) Rate of nitrate metabolism in a high-nitrate sample $(6 \mathrm{~g} \mathrm{~N} / \mathrm{kg})$. (O), nitrate; $(\triangle)$, nitrite; $(\odot)$, ammonia. Values are means, with their standard errors represented by vertical bars, for six determinations.

\section{RESULTS}

Effect of nitrate and its reduction products on digestion in vitro

The effect of nitrate and its reduction products on the rate of digestion in vitro of a Kikuyu grass sample is shown in Fig. 1(a). Nitrate decreased the rate but not the extent of digestion. Maximum digestion was delayed by approximately $24 \mathrm{~h}$.

The reduction of nitrate by a mixed population of rumen microbes is shown in Fig. 1(b). The nitrate concentration in the digest decreased rapidly during the first $24 \mathrm{~h}$ of digestion. Nitrite concentrations reached a peak after about $18 \mathrm{~h}$ and then decreased to zero after about $30 \mathrm{~h}$. Ammonia levels increased and remained high throughout the digestion period.

Digests of low-nitrate Kikuyu grass, supplemented with either nitrate, nitrite or ammonia, showed a negligible effect of ammonium ions on digestibility, but the addition of both nitrate and nitrite markedly lowered the digestibility (Table 1). The effect of nitrite on digestion was much more severe than that of nitrate.

The effect of tungstate, an inhibitor of nitrate reductase (NADPH) $(E C 1.6 .6 .3)$, on the digestibility of a Kikuyu grass sample in the presence and absence of nitrate is presented in Table 2. Tungstate did not have much effect on the digestibility of Kikuyu grass low in nitrate. For the grass high in nitrate only a partial inhibition of nitrate reduction was obtained, but nitrite accumulation was reduced. Digestibility was only decreased in the presence of nitrite. 
Table 1. Effect of the addition of nitrate, nitrite and ammonia on the digestion in vitro of low-nitrate Kikuyu grass (Pennisetum clandestinum) samples

(Ammonia was added as ammonium sulphate, while nitrate and nitrite were added as potassium salts, all at concentrations of $6 \mathrm{~g}$ nitrogen $/ \mathrm{kg}$, before digestion. Values are means with their standard errors, for five determinations)

\begin{tabular}{cccc}
\hline \hline $\begin{array}{c}\text { Digestion } \\
\text { period }(\mathrm{h})\end{array}$ & $\begin{array}{c}\text { Addition } \\
(6 \mathrm{~g} \mathrm{~N} / \mathrm{kg})\end{array}$ & Digestibility & $\mathrm{SE}$ \\
\hline \multirow{2}{*}{24} & $\mathrm{NO}_{3}^{-}$ & 0.240 & 0.004 \\
& $\mathrm{NO}_{2}^{-}$ & $0 \cdot 194$ & 0.006 \\
& $\mathrm{NH}_{4}^{+}$ & 0.347 & 0.006 \\
& $\mathrm{Control}^{*} 48$ & 0.353 & 0.001 \\
& $\mathrm{NO}_{3}^{-}$ & 0.357 & 0.014 \\
& $\mathrm{NO}_{2}^{-}$ & 0.342 & 0.003 \\
& $\mathrm{NH}_{4}^{+}$ & 0.576 & 0.003 \\
& Control & 0.584 & 0.004 \\
\hline \hline
\end{tabular}

Table 2. Effect of tungstate on nitrate reduction and digestibility in vitro of high-nitrate Kikuyu grass (Pennisetum clandestinum) samples

(For high-nitrate samples the nitrate-nitrogen contents were adjusted to $6 \mathrm{~g} / \mathrm{kg}$ dry matter by the addition of potassium nitrate before incubation. Tungstate was added as sodium tungstate (10 mmol). Values are means with their standard errors for four determinations)

\begin{tabular}{|c|c|c|c|c|c|c|c|c|}
\hline \multicolumn{3}{|c|}{ Treatment } & \multirow{2}{*}{\multicolumn{2}{|c|}{$\begin{array}{c}\text { Nitrate } \\
\text { content } \\
(\mathrm{mg} / \mathrm{l})\end{array}$}} & \multirow{2}{*}{\multicolumn{2}{|c|}{$\begin{array}{l}\text { Nitrite } \\
\text { content } \\
(\mathrm{mg} / \mathrm{l})\end{array}$}} & \multirow{2}{*}{\multicolumn{2}{|c|}{ Digestibility }} \\
\hline \multirow{2}{*}{$\begin{array}{l}\text { Digestion } \\
\text { period } \\
\text { (h) }\end{array}$} & \multirow{2}{*}{$\begin{array}{l}\text { Nitrate } \\
(6 \mathrm{~g} / \mathrm{kg})\end{array}$} & \multirow{2}{*}{$\begin{array}{l}\text { Tungstate } \\
\text { (10 mmol) }\end{array}$} & & & & & & \\
\hline & & & Mean & $\mathbf{S E}$ & Mean & $\mathrm{SE}$ & Mean & $\mathrm{SE}$ \\
\hline \multirow[t]{4}{*}{24} & - & + & $5 \cdot 8$ & 0.2 & 0.0 & - & 0.406 & 0.002 \\
\hline & - & - & 5.4 & $0 \cdot 1$ & 0.0 & - & 0.376 & 0.007 \\
\hline & + & + & $14 \cdot 6$ & 0.2 & $0 \cdot 1$ & $0 \cdot 0$ & 0.393 & $0 \cdot 004$ \\
\hline & $t$ & - & $13 \cdot 2$ & $0 \cdot 8$ & $9 \cdot 4$ & 0.1 & $0 \cdot 314$ & 0.005 \\
\hline \multirow[t]{4}{*}{48} & - & + & 7.6 & $0 \cdot 2$ & 0.0 & - & 0.574 & 0.007 \\
\hline & - & - & $6 \cdot 3$ & 0.2 & $0 \cdot 0$ & - & 0.564 & 0.004 \\
\hline & + & + & $8 \cdot 6$ & $0 \cdot 2$ & $0 \cdot 0$ & - & 0.569 & 0.005 \\
\hline & + & - & 7.6 & $0 \cdot 2$ & $0-0$ & - & 0.467 & 0.008 \\
\hline
\end{tabular}

$$
- \text {, Absent; +, present. }
$$

\section{Effect of nitrite on microbial growth and carbohydrase activity}

A study of the effect of nitrite on rumen bacterial numbers, which distinguished between cellulolytic, xylanolytic and total microbial populations showed that the number of all bacterial groups decreased rapidly as nitrite was formed in the digest (Fig. 2). At peak nitrite values $(10 \mathrm{mg} / \mathrm{l})$ cellulolytic microbes were reduced by $64 \%$, xylanolytic microbes by $25 \%$ and total viable bacteria by $57 \%$.

A study of the relation between the number of microbes present in the digest and the carbohydrase activity associated with the grass residue after digestion in vitro, showed that the decrease in xylanase and cellulase activity largely paralleled the change in numbers of the corresponding microbes (Fig. 3).

Change in volatile fatty acid concentration in the presence of nitrite

The volatile fatty acid composition of a Kikuyu-grass digest in vitro in the presence and absence of nitrate is given in Table 3. Results show that although nitrite caused a 

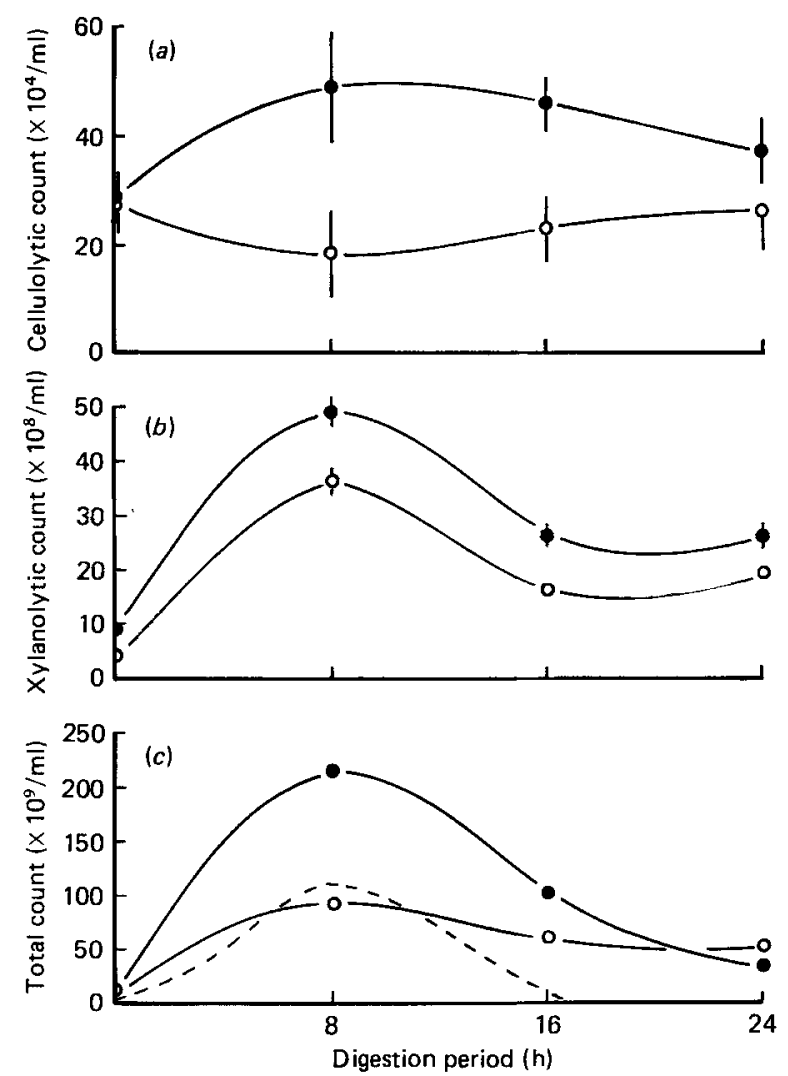

Fig. 2. Effect of nitrite on (a) cellulolytic, $(b)$ xylanolytic and $(c)$ total viable bacterial count of Kikuyu grass (Pennisetum clandestinum) digests in vitro. For high-nitrite digests the nitrate-nitrogen contents of the grass samples were adjusted to $6 \mathrm{~g} / \mathrm{kg}$ dry matter before digestion. (----), Nitrite peak; $(O)$, highnitrite digest; (O), control digest (low-nitrite). Values are means, with their standard errors represented by vertical bars, for five determinations.

considerable reduction in the concentration of total volatile fatty acids and a change in the molar ratios of individual fatty acids, the concentrations of branched-chain acids, essential for the growth of cellulolytic rumen bacteria, did not decrease much during digestion.

\section{The effect of nitrite on redox potential and digestibility in vitro}

The redox potential of an in vitro digest of Kikuyu grass in the presence and absence of nitrate, was followed over a digestion period of 26 h. Results presented in Fig. 4 show that the presence of nitrite in the digest resulted in more positive oxidation-reduction potentials.

A study of the effect of redox potential on digestibility was undertaken. By the addition of cysteine, the redox potential in the presence and absence of nitrite could be maintained at approximately $-125 \mathrm{mV}$ throughout the digestion period. Results presented in Table 4 show that although cysteine improved the digestibility slightly in the presence of nitrite, these values were still much lower than the digestibility values in the absence of nitrite.

\section{Effect of nitrite on the specific growth rate of individual rumen bacterial species}

The effect of nitrite on the specific growth rates at $\mathrm{pH} 6.0$ and 6.8 of pure cultures of the major cellulolytic bacteria in the rumen and Selenomonas ruminantium, a non-cellulolytic 


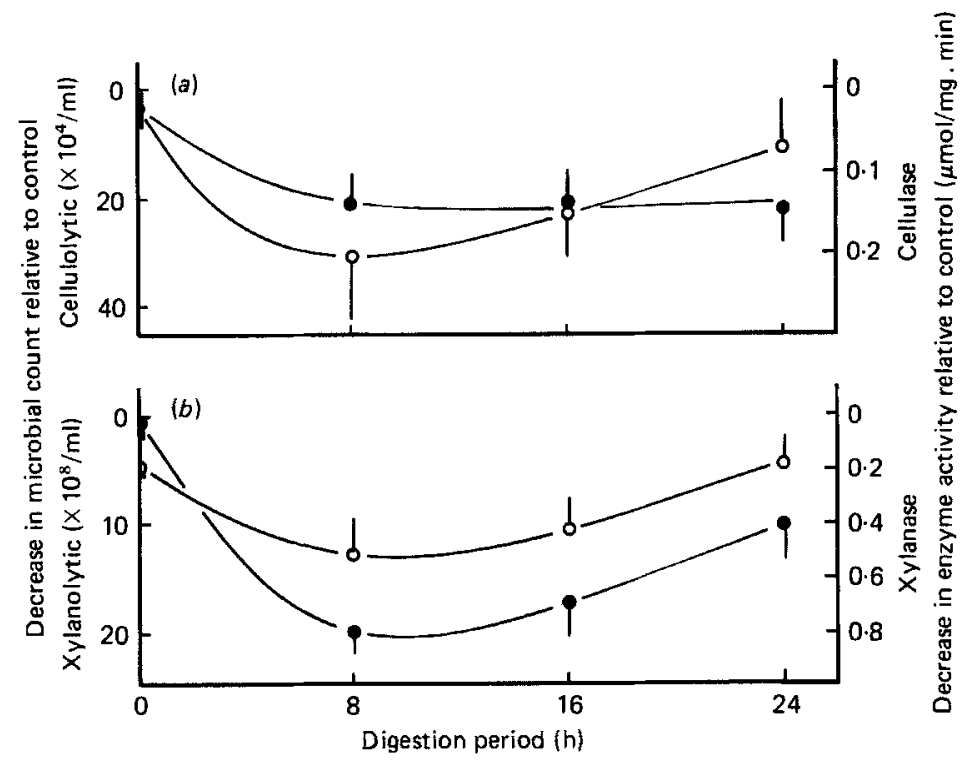

Fig. 3. Change in (a) viable cellulolytic microbial count and cellulase activity and $(b)$ viable xylanolytic microbial count and xylanase activity of a high-nitrite Kikuyu grass (Pennisetum clandestinum) digest in vitro over the digestion period, relative to the low-nitrite control digest. For the high-nitrite digests the nitrate-nitrogen contents of the grass samples were adjusted to $6 \mathrm{~g} / \mathrm{kg}$ before digestion. (O), Microbial count ; (O), enzyme activity. Values are means, with their standard errors represented by vertical bars, for five determinations.

Table 3. Effect of nitrite on volatile fatty acid production during digestion in vitro of Kikuyu grass (Pennisetum clandestinum) samples

(For high-nitrite digests the nitrate-nitrogen contents of the grass samples were adjusted to $6 \mathrm{~g} / \mathrm{kg}$ before digestion. Values are means with their standard errors for three determinations)

\begin{tabular}{|c|c|c|c|c|c|}
\hline \multirow{3}{*}{$\begin{array}{l}\text { Digestion } \\
\text { period (h) }\end{array}$} & \multirow{3}{*}{$\begin{array}{l}\text { Volatile } \\
\text { fatty acid }\end{array}$} & \multicolumn{4}{|c|}{ Volatile fatty acid content $(\mathrm{mmol} / \mathrm{l})$} \\
\hline & & \multicolumn{2}{|c|}{$\begin{array}{l}\text { High-nitrite } \\
\text { digest }\end{array}$} & \multicolumn{2}{|c|}{$\begin{array}{c}\text { Low-nitrite } \\
\text { digest }\end{array}$} \\
\hline & & Mean & $\mathrm{SE}$ & Mean & $\mathrm{SE}$ \\
\hline \multirow[t]{7}{*}{7} & Acetic & 12.65 & 0.07 & $14 \cdot 31$ & 0.19 \\
\hline & Propionic & 3.44 & 0.03 & 3.90 & 0.04 \\
\hline & Isobutyric & $0 \cdot 17$ & 0.00 & $0 \cdot 18$ & 0.01 \\
\hline & Butyric & $1 \cdot 21$ & 0.01 & $1 \cdot 35$ & 0.02 \\
\hline & Isovaleric & $0 \cdot 18$ & 0.00 & $0 \cdot 19$ & 0.01 \\
\hline & Valeric & $0 \cdot 14$ & 0.01 & $0 \cdot 16$ & 0.01 \\
\hline & Total & $17 \cdot 79$ & - & $20 \cdot 09$ & - \\
\hline \multirow[t]{7}{*}{24} & Acetic & $19 \cdot 15$ & 0.07 & $22 \cdot 09$ & 0.22 \\
\hline & Propionic & $5 \cdot 40$ & 0.00 & $7 \cdot 40$ & 0.09 \\
\hline & Isobutyric & 0.22 & $0 \cdot 01$ & 0.22 & 0.01 \\
\hline & Butyric & $1 \cdot 71$ & 0.04 & $2 \cdot 17$ & 0.02 \\
\hline & Isovaleric & 0.22 & 0.01 & $0 \cdot 21$ & 0.01 \\
\hline & Valeric & 0.24 & 0.01 & $0 \cdot 26$ & 0.01 \\
\hline & Total & 26.94 & - & $32 \cdot 35$ & - \\
\hline
\end{tabular}




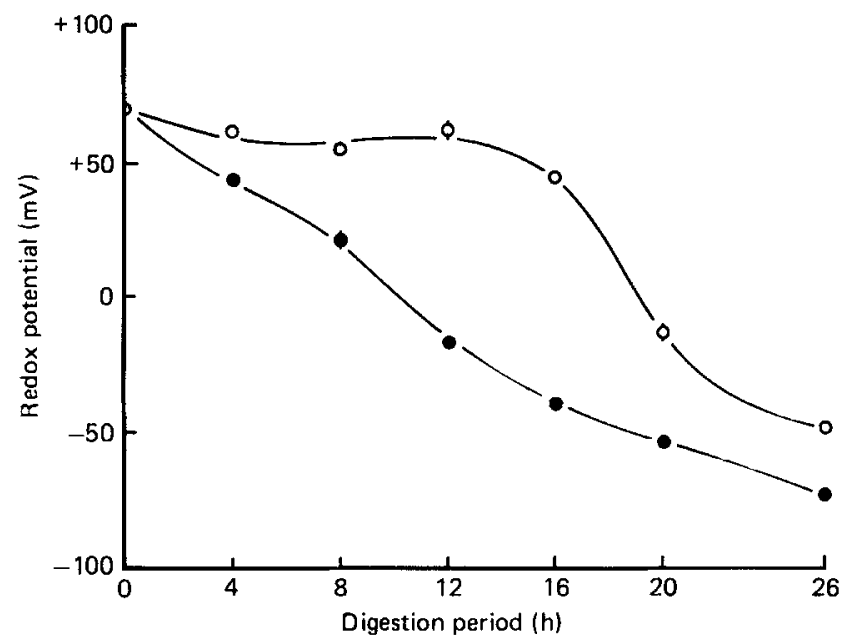

Fig. 4. Effect of nitrate on the redox potential of a Kikuyu grass (Pennisetum clandestinum) digest in vitro. For high-nitrate digests the nitrate-nitrogen contents of the grass samples were adjusted to 6 $\mathrm{g} / \mathrm{kg}$ before digestion. (O), high-nitrate digest; $(\mathbf{O})$, low-nitrate digest. Values are means, with their standard errors represented by vertical bars, for three determinations.

Table 4. Effect of low redox potential (by the addition of cysteine to a concentration of $3.3 \mathrm{mmol} / \mathrm{l}$ ) on the digestibility in vitro of a high-nitrite Kikuyu grass (Pennisetum clandestinum) digest

(For high-nitrite digests the nitrate-nitrogen contents of the grass samples were adjusted to $6 \mathrm{~g} / \mathrm{kg}$ before digestion. Values are means with their standard errors for four determinations)

\begin{tabular}{|c|c|c|c|c|}
\hline \multicolumn{2}{|c|}{ Treatment } & \multirow{3}{*}{$\begin{array}{c}\text { Mean redox } \\
\text { potential over } \\
24 \text { h digestion } \\
(\mathrm{mV})\end{array}$} & \multirow{2}{*}{\multicolumn{2}{|c|}{ Digestibility }} \\
\hline \multirow{2}{*}{$\begin{array}{l}\text { Nitrate } \\
(6 \mathrm{~g} / \mathrm{kg})\end{array}$} & \multirow{2}{*}{$\begin{array}{c}\text { Cysteine } \\
(3.3 \mathrm{mmol} / \mathrm{l})\end{array}$} & & & \\
\hline & & & Mean & $\mathrm{SE}$ \\
\hline- & - & -20 & 0.485 & 0.003 \\
\hline- & + & -125 & 0.463 & 0.005 \\
\hline+ & - & +2 & 0.369 & 0.005 \\
\hline+ & + & -122 & 0.397 & 0.004 \\
\hline
\end{tabular}

species, is given in Fig. 5. At pH 6.8 the growth of Ruminococcus flavefaciens, Butyrivibrio fibrisolvens and Bacteroides succinogenes was inhibited by nitrite- $\mathrm{N}$ concentrations of the order of $4 \mathrm{mg} / \mathrm{l}$, while the growth of Ruminococcus albus and Selenomonas ruminantium was hardly affected at all.

In the absence of nitrite Selenomonas ruminantium, Bacteroides succinogenes and Ruminococcus albus showed a lower specific growth rate at $\mathrm{pH} 6.0$, while Ruminococcus flavefaciens and Butyrivibrio fibrisolvens did not grow at all. In the presence of nitrite the slopes of the growth curves for Bacteroides succinogenes and Ruminococcus albus were similar at $\mathrm{pH} 6.0$ and 6.8 , but at $\mathrm{pH} 6.0$ growth of Selenomonas ruminantium was completely arrested at a nitrite- $\mathrm{N}$ concentration of $2 \mathrm{mg} / \mathrm{l}$. 


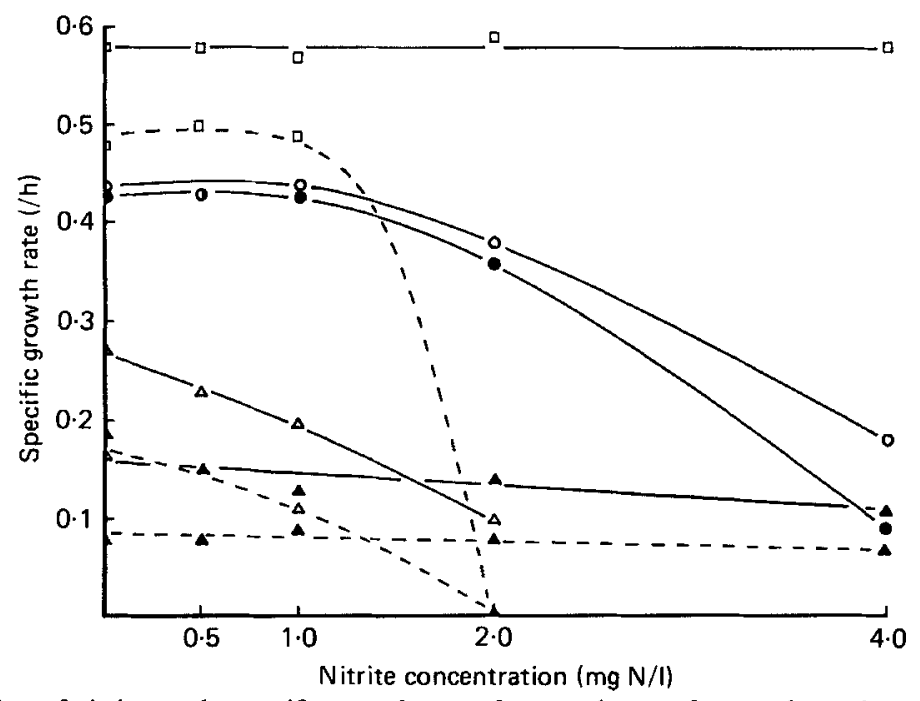

Fig. 5. Effect of nitrite on the specific growth rate of pure cultures of rumen bacteria at pH 6.8 and 6.0 . Nitrite was added to the culture as potassium nitrite. (O), Ruminococcus favefaciens FD1; (O), Butyrivibrio fibrisolvens $\mathrm{Ce} 51 ;(\triangle)$, Bacteroides succinogenes $\mathrm{S} 85 ;(\mathbf{A})$, Ruminococcus albus 22.08.6A;

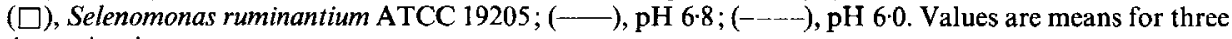
determinations.

\section{DISCUSSION}

Factor responsible for reduced digestibility in high-nitrate grasses

The decrease in rate of digestion by nitrate in the digest (Fig. 1(a)), suggests that nitrate or a reduction product of nitrate temporarily present in the digest, affects digestibility. The reduction of nitrate to nitrite and subsequently to ammonia, is well documented and seems to be the major pathway for the reduction of nitrate by rumen microbes (Lewis, 1951; Jones, 1972). The exceptionally high level of ammonia observed in the present investigation (Fig. 1(b)) was derived from urea present in the buffer used in these experiments, and masked the ammonia derived from the reduction of nitrite. During the period of maximum suppression of digestion, nitrate, nitrite and ammonia were present in the digest and could all have contributed to the observed reduction in digestibility.

Supplementing a low-nitrate digest with either nitrate, nitrite or ammonia, showed a marked reduction in digestibility by nitrate and nitrite but no effect by ammonia (Table 1 ). Nitrate reduced digestibility to a lesser extent than nitrite, but this effect could have been due to the conversion of nitrate to nitrite during digestion. The involvement of nitrate as such in the suppression of digestion, could be disproved by restricting the formation of nitrite by the addition of sodium tungstate, an inhibitor of nitrate reductase (NADPH) (Taniguchi \& Itagaki, 1960). Total inhibition of nitrate reduction could not be achieved as tungstate prevents the synthesis of an active enzyme, but does not inhibit the active enzyme already formed (Prins et al. 1980). However, nitrate reduction was sufficiently suppressed, relative to nitrite reduction, to prevent the accumulation of nitrite in the digest (Table 2). In the presence of nitrate and the absence of nitrite, digestion was not reduced. Results therefore suggest that nitrite is the primary factor reducing digestibility in rumen digests high in nitrate.

\section{Effect of nitrite on microbial growth and carbohydrase activity}

A reduction in digestibility of a feed sample involves primarily a reduction in the solubilization of the structural components, such as cellulose and hemicellulose. Hall et al. 
(1960) demonstrated a reduction in digestibility of pure cellulose (Solkafloc) in the presence of nitrate. In the present investigation further evidence of the effect of nitrate on the breakdown of structural components is given by the observed reduction in the cellulolytic and xylanolytic microbial population in the presence of nitrite, with a concomitant reduction in cellulase and xylanase activity (Figs. 2 and 3). A study of the carbohydrase activity in the rumen digests is complicated by the fact that the component enzymes form large-molecular-weight complexes which are not easily separated from the substrate or from each other (Francis et al. 1978; Gawthorne, 1979). Values for cellulase activity and xylanase activity could each be due to the action of more than one enzyme. These values must also be regarded as relative, as they represent only the activity associated with particulate matter in the digest. However, according to Francis et al. (1978) this represents more than $90 \%$ of the total activity.

\section{The mode of action of nitrite on rumen microbial growth}

Nitrite manifests its effect through a reduction in microbial growth, with cellulolytic microbes being affected most severely. To the authors' knowledge, no information is available on the mode of action of nitrite as an inhibitor of rumen cellulolytic and xylanolytic bacteria. However, nitrite has long been used as a antimicrobial agent in the meat-processing industry (Perigo \& Roberts, 1968).

As a meat preservative the inhibitory properties of nitrite appear to be quite complex and could be attributed to more than one mechanism. Morris \& Hansen (1981) attributed the antimicrobial effect of nitrite on Bacillus cereus to a reaction of nitrite with sulphydryl compounds to form nitrosothiols which, in turn, react with sulphydryl groups on the bacterial membrane or spore coat. Castellani \& Niven (1955) showed that the bacteriostatic effect of nitrite on Staphylococcus aureus is $\mathrm{pH}$-dependent and is directly proportional to the amount of undissociated nitrous acid formed from nitrite at low $\mathrm{pH}$. Nitrous acid could react with a wide range of substances such as myoglobin, ascorbic acid, phenols, secondary amines and amino and thiol groups (O'Leary \& Solberg, 1976). Rowe et al. (1979) suggested that nitrite exerts its effect specifically at the electron-carrier level. In the present study several factors which could contribute to a reduction in rumen microbial growth were investigated.

Cellulolytic rumen bacteria have an absolute requirement for certain branched-chain fatty acids (Allison et al. 1958). The growth rate of cellulolytic bacteria on a cellulose-urea medium, shows an initial lag phase which Miura et al. (1983) attributed to the time required for the production of branched-chain fatty acids. It is further known that nitrate causes marked changes in the composition of the major volatile fatty acids in rumen digests (Bryant, 1965). However, since the concentration of branched-chain volatile fatty acids was maintained during digestion in the presence of nitrite (Table 3), it seems unlikely that a lack of these acids contributed to the more-severe effect of nitrite on the growth of cellulolytic bacteria in the present investigation.

The redox potential of microbial cultures is a measure of the degree of anaerobiosis in the growth environment. For normal growth the predominant rumen microbes require a low redox potential in the ambient medium and redox potentials of $-300 \mathrm{mV}$ or less have been reported for the rumen contents of cattle (Smith \& Hungate, 1958). Hanke \& Katz (1943) showed that redox potential, as such, could be a growth-limiting factor for certain anaerobic microbes. However, in most instances oxygen seems to be the primary factor interfering with the growth of anaerobic bacteria (Morris, 1975). Nitrite is a highly reactive substance and maintenance of a low redox potential in culture media containing nitrite is difficult (Allison \& Reddy, 1984). Due to its oxidizing properties it could increase the redox potential of rumen digests to growth-limiting values. 
As a result of difficulties in standardizing redox electrodes (Kjaergaard, 1977), the redox values presented in Fig. 4 and Table 4 should be considered as relative. Nevertheless, results clearly showed that nitrite had a marked effect on the redox potential of the digest. The small improvement in digestibility on lowering the redox potential by means of cysteine, could be ascribed to a reduction in nitrite formation in the presence of cysteine. After $8 \mathrm{~h}$ digestion the nitrite- $\mathrm{N}$ contents in the presence and absence of cysteine were 11.3 and $15.0 \mathrm{mg} / 1$ respectively and after $16 \mathrm{~h}$ of digestion, 1.0 and $2.5 \mathrm{mg} / 1$ respectively. This could be due to a depression in the production of nitrate reductase (NADPH) in the presence of cysteine (Azoulay et al. 1969).

The much-lower digestibility values obtained in the presence of nitrite compared with the digestibility in the absence of nitrite, regardless of the redox potential of the digest, suggest that the redox potential as such did not affect microbial growth and therefore did not contribute to the low digestibility. The results therefore suggest a more-direct effect of nitrite on the growth of rumen bacteria, possibly by affecting the energy metabolism of the bacteria as observed for the non-rumen organisms, Escherichia coli and Pseudomonas aeruginosa, by Eagon et al. (1979) and Rowe et al. (1979). These workers showed that nitrite inhibits bacteria which produce ATP via electron transport systems, but has no effect on microbes which lack cytochromes and rely on glycolysis for ATP generation. This suggests inhibition at the electron-carrier level.

Since some information exists on the mechanism of ATP synthesis in several major rumen bacteria, this knowledge was used to gain some insight into the mode of action of nitrite on rumen microbial growth. Thauer et al. (1977) demonstrated an electron transport system in Ruminococcus flavefaciens, although evidence for ATP synthesis via electron transport is lacking (Hopgood \& Walker, 1967, 1969). Butyrivibrio fibrisolvens obtains less than $50 \%$ of its ATP via electron-transport-mediated processes, while substrate-level and electron transport systems contribute equally to energy production in Bacteriodes succinogenes (Dawson et al. 1979). The growth of these bacteria was severely affected by nitrite in the growth media (Fig. 5). In contrast, the growth of Selenomonas ruminantium and Ruminococcus albus, which obtain ATP entirely via substrate-level phosphorylation (Dawson et al. 1979; Thauer \& Kröger, 1984), was hardly affected at all by nitrite. Increasing the nitrite- $\mathrm{N}$ concentration of the medium to $32 \mathrm{mg} / \mathrm{l}$ caused a very gradual decrease in growth of these bacteria, possibly suggesting inhibition by the general affinity of nitrite for essential sulphydryl groups.

Although $\mathrm{pH} 6.0$ does not favour growth, the growth of rumen bacteria was studied at $\mathrm{pH} 6.0$, since a more pronounced reduction in bacterial growth in the presence of nitrite at low $\mathrm{pH}$ could indicate nitrous acid as the substance inhibiting bacterial growth. Decreased or lack of growth in the absence of nitrite at $\mathrm{pH} 6.0$, however, indicated that the $\mathrm{pH}$ is close to, or exceeds the lower $\mathrm{pH}$ limit for growth of the bacteria investigated (Fig. 5). Since the slopes of the growth curves for Ruminicoccus albus and Bacteroides succinogenes were identical at $\mathrm{pH} 6.0$ and 6.8 , nitrite inhibition in these microbes did not seem to depend on nitrous acid formation. In contrast, the $\mathrm{pH}$ had a marked effect on the growth of Selenomonas ruminantium and inhibition could be due to nitrous acid (formed under mild acidic conditions) reacting with essential sulphydryl groups, as proposed for Clostridium perfringens (O'Leary \& Solberg, 1976).

Ruminants can adapt to nitrate in their diet by an increase in the nitrate-metabolizing bacteria in the rumen (Allison \& Reddy, 1984). However, if the capacity of the nitritereducing microbes is exceeded, nitrite will accumulate. Symptoms of methaemoglobinaemia in ruminants could be expected if the nitrite- $\mathrm{N}$ level in the rumen is of the order of $80 \mathrm{mg} / 1$ (Kemp et al. 1976, 1977). The present study suggests that the primary action of nitrite in the rumen is an inhibition of the electron transport system of rumen microbes at nitrite- $\mathrm{N}$ 
concentrations as low as $4 \mathrm{mg} / \mathrm{l}$. Bacteria not possessing an electron transport system seem to be affected less. In the present study protozoa probably played an insignificant role, since protozoa do not usually survive for longer than $6 \mathrm{~h}$ in these in vitro systems. Protozoa, abundant in the intact rumen, would probably also be susceptible to nitrite, depending on their reliance on electron transport for energy production. The extent of the effect of nitrate on rumen fermentation will therefore depend on the degree to which nitrite accumulates in the digest and on the ability of the cellulolytic microbes in particular, to change towards a population containing increased proportions of species capable of tolerating nitrite.

Although results from the present investigation on in vitro digests and pure cultures of rumen bacteria may not be directly applicable to the in vivo situation, these results do suggest that digestibility and, therefore, animal performance could be affected long before symptoms of toxicity in ruminants become apparent.

The authors express sincere appreciation to Mr D. L. Figenschou, Mrs P. L. EscottWatson and Miss M. Paling for their highly competent technical assistance.

\section{REFERENCES}

Allison, M. J., Bryant, M. P. \& Doetsch, R. N. (1958). Science 128, 474-475.

Allison, M. J. \& Reddy, C. A. (1984). In Current Perspectives in Microbial Ecology, pp. $248-256$ [M. J. Kelly and C. A. Reddy, editors]. Washington, DC: American Society for Microbiology.

Asbury, A. C. \& Rhode, E. A. (1964). American Journal of Veterinary Research 25, 1010-1013.

Azoulay, E., Puig, J. \& Martins Rosado De Sousa, M. L. (1969). Annales de IInstitut Pasteur, Paris 117, 474-485.

Bryant, A. M. (1965). New Zealand Journal of Agricultural Research 8, 118-125.

Caldwell, D. R. \& Bryant, M. P. (1966). Applied Microbiology 14, 794-801.

Castellani, A. G. \& Niven, C. F. (1955). Applied Microbiology 3, 154-159.

Cataldo, D. A., Haroon, M., Schrader, L. E. \& Young, V. L. (1975). Communications in Soil Science and Plant Analysis 6, 71-80.

Committee on Nitrite and Alternative Curing Agents in Food (1981). The Health Effects of Nitrate, Nitrite and N-Nitroso Compounds. Washington, DC: National Academy Press.

Dawson, K. A., Preziosi, M. C. \& Caldwell, D. R. (1979). Journal of Bacteriology 139, 384-392.

Eagon, R. G., Hodge, T. W., Rake, J. B. \& Yarbrough, J. M. (1979). Canadian Journal of Microbiology 25, $798-802$.

Francis, G. L., Gawthorne, J. M. \& Storer, G. B. (1978). Applied and Environmental Microbiology 36, 643-649.

Gawthorne, J. M. (1979). Annales De Recherches Veterinaires 10, 249-250.

Hall, O. G., Gaddy, C. D. \& Hobbs, C. S. (1960). Journal of Animal Science 19, 1305.

Hanke, M. E. \& Katz, Y. J. (1943). Archives of Biochemistry and Biophysics 2, 183-200.

Hansen, J. N. \& Levin, R. A. (1975). Applied Microbiology 30, 862-869.

Holtenius, P. (1957). Acta Agriculturae Scandinavica 7, 113-163.

Hopgood, M. F. \& Walker, D. J. (1967). Australian Journal of Biological Science 20, 183-192.

Hopgood, M. F. \& Walker, D. J. (1969). Australian Journal of Biological Science 22, 1413-1424.

Jamieson, N. D. (1959). New Zealand Journal of Agricultural Research 2, 314-328.

Jones, G. A. (1972). Canadian Journal of Microbiology 18, 1783-1787.

Kemp. A., Geurink, J. H., Haalstra, R. T. \& Malestein, A. (1976). Stikstof 19, 4048.

Kemp, A., Geurink, J. H., Haalstra, R. T. \& Malestein, A. (1977). Netherlands Journal of Agricultural Science 25, $51-62$.

Kistner, A. (1960). Journal of General Microbiology 23, 565-576.

Kjaergaard, L. (1977). In Advances in Biochemical Engineering, vol. 7, pp. 131-150 [T. K. Ghose, A. Fiechter and N. Blakebrough, editors]. Berlin: Springer Verlag.

Koch, A. L. (1981). In Manual of Methods for General Bacteriology, pp. 179-207 [P. Gerhardt, R. G. E. Murray, R. N. Costilow, E. W. Nester, W. A. Wood, N. R. Krieg and G. B. Phillips, editors]. Washington, DC: American Society for Microbiology.

Krishnamurti, C. R. \& Kitts, W. D. (1969). Canadian Journal of Microbiology 15, 1373-1379.

Kromann, R. P., Weikel, J. M. \& Falen, L. F. (1976). College of Agricultural Research Centre Bulletin no. 821. Washington DC: Washington State University.

Lewis, D. (1951). Biochemistry Journal 49, 149-153.

Marais, J. P. (1966). South African Journal of Agricultural Science 9, 267-268.

Marais, J. P. (1980). Agroanimalia 12, 7-11. 
Marais, J. P., De Wit, J. L. \& Quicke, G. V. (1966). Analytical Biochemistry 15, 373-381.

Minson, D. J. \& McLeod, M. N. (1972). Division of Tropical Pastures Technical Paper no. 8. Melbourne, Australia: Commonwealth Scientific and Industrial Organisation.

Miura, H., Horiguchi, M., Ogimoto, K. \& Matsumoto, T. (1983). Applied and Environmental Microbiology 45, 726-729.

Miyazaki, A., Okamoto, K., Tsuda, E., Kawashima, R. \& Uesaka, S. (1974). Japanese Journal of Zootechnical Science 45, 183-188.

Morris, J. G. (1975). Advances in Microbial Physiology 12, 169-246.

Morris, S. L. \& Hansen, J. N. (1981). Journal of Bacteriology 148, 465-471.

Nicholas, D. J. D. \& Nason, A. (1957). In Methods in Enzymology, vol. 3, pp. 981-984 (S. P. Colowick and N. D. Kaplan, editors]. New York: Academic Press.

O'Leary, V. \& Solberg, M. (1976). Applied and Environmental Microbiology 31, 208-212.

Perigo, J. A. \& Roberts, T. A. (1968). Journal of Food Technology 2, 91-94.

Prins, R. A., Cline-Theil, W., Malestein, A.\& Counotte, G. H. M. (1980). Applied and Environmental Microbiology 40, 163-165.

Raun, N. S. \& Burroughs, W. (1962). Journal of Animal Science 21, 454-457.

Rowe, J. J., Yarbrough, J. M., Rake, J. B. \& Eagon, R. G. (1979). Current Microbiology 2, 51-54.

Smith, P. H. \& Hungate, R. E. (1958). Journal of Bacteriology 75, 713-718.

Taiz, L. \& Honigman, W. A. (1976). Plant Physiology 58, 380-386.

Taniguchi, S. \& Itagaki, E. (1960). Biochimica et Biophysica Acta 44, 263-279.

Thauer, R. K., Jungermann, K. \& Decker, K. (1977). Bacteriological Review 41, 100-180.

Thauer, R. K. \& Kröger, A. (1984). In Herbivore Nutrition in the Subtropics and Tropics, pp. 399-407. [E. M. C. Gilchrist and R. I. Mackie, editors]. South Africa: Science Press.

Tilley, J. M. A. \& Terry, R. A. (1963). Journal of the British Grassland Society 18, 104-111.

Turner, C. A. \& Kienholz, E. W. (1972). Feedstuffs 44, 28-30.

Van Broekhoven, L. W. \& Davies, J. A. R. (1980). Netherlands Journal of Agricultural Science 28, $238-241$.

Van Broekhoven, L. W. \& Davies, J. A. R. (1981). Netherlands Journal of Agricultural Science 29, $173-177$.

Vertregt, N. (1977). Netherlands Journal of Agricultural Science 25, 243-254.

Weatherburn, M. W. (1967). Analytical Chemistry 39, 971-974.

Yarbrough, J. M., Rake, J. B. \& Eagon, R. G. (1980). Applied and Environmental Microbiology 39, 831-834. 